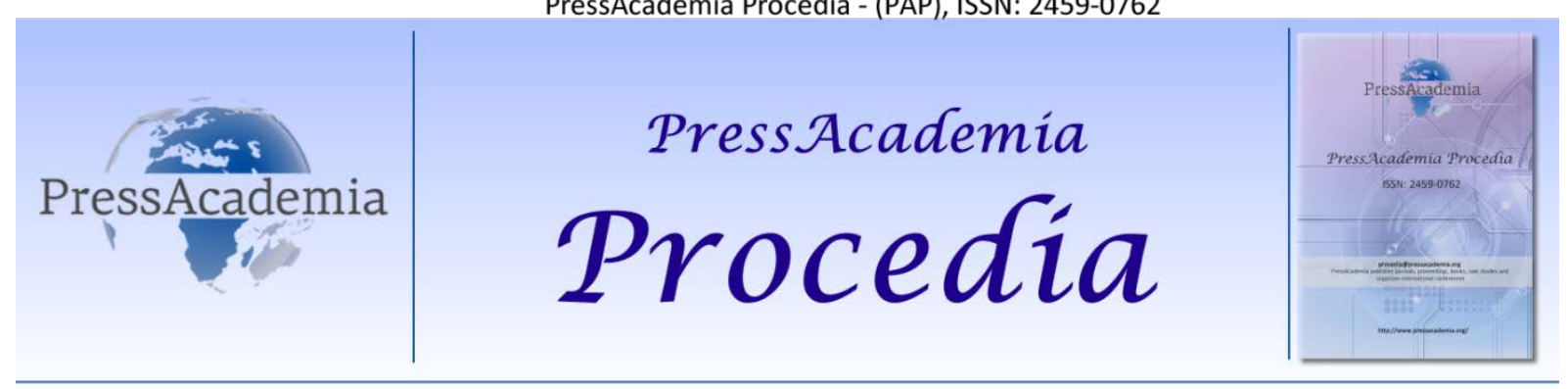

Global Business Research Congress (GBRC), May 26-27, 2016, Istanbul, Turkey.

\title{
E-COMMERCE IN TURKEY
}

\section{DOI: 10.17261/Pressacademia.2016118648}

\section{Ali Acilar}

Bilecik Şeyh Edebali Üniversitesi. ali.acilar@bilecik.edu.tr

\begin{abstract}
As the Internet has become an important part of our lives, it has also been used for business transactions and electronic commerce (ecommerce) concept has entered our lives, with the wide penetration of the Internet worldwide. Even though, traditional commerce is still dominant, e-commerce volume tends to increase every year. Along with the improvement of Internet infrastructure and the increasing number of Internet users, e-commerce volume increased in Turkey too. In this study, current status and development of e-commerce in Turkey over the years is discussed, using E-Commerce Transaction Reports prepared by The Interbank Card Center, findings of the surveys on Information and Communication Technology Usage in Households and Enterprises, conducted by Turkish Statistical Institute and Eurostat e-commerce statistics for individuals.
\end{abstract}

Keywords: E-commerce, Turkey, e-commerce volume

JEL Codes: L81, M10, M30

\section{E-TICARETTE TÜRKIYE NE DURUMDA?}

\section{ÖZET}

Internetin dünya genelinde yaygınlaşması ile birlikte, internet günlük hayatımızın önemli bir parçası haline gelmiş olmakla birlikte, ticari işlemlerin gerçekleştirilmesi için de kullanılmaya başlamış ve e-ticaret kavramı hayatımıza girmiştir. Günümüzde geleneksel ticaret halen ağırlı̆ııı koruyor olsa da elektronik ticaret (e-ticaret) hacmi her yıl artma eğilimindedir. Ülkemizde de gerek internet altyapısının iyileştirilmesi ve internet kullanıcı sayısının artması ile birlikte e-ticaret hacmi de genişlemiştir. Bu çalışmada Bankalararası Kart Merkezi (BKM) Internetten Yapılan Kartlı Ödeme İşlemleri istatistikleri ve Türkiye İstatistik Kurumu (TÜiK) tarafından yapılan Girişimlerde Bilişim Teknolojileri Kullanım Araştırması ve Hanehalkı Bilişim Teknolojileri Kullanım Araştırması istatistikleri ile Avrupa istatistik Ofisi (Eurostat) eticaret istatistikleri kullanılarak ülkemizde e-ticaretin yıllar içerisindeki gelişimi ve mevcut durumu ele alınmaktadır.

Anahtar Kelimeler: E-ticaret, Türkiye, e-ticaret hacmi

JEL Kodları: L81, M10, M30

\section{GiRiş}

Günümüz bilgi ve iletişim teknolojileri, özellikle internet ve Dünya Çapında Ağ (World Wide Web, WWW), eğitimden sağlığa, eğlenceden iletişime, sosyal hayattan iş hayatına kadar, yaşantımızın hemen her alanında değişikliklere neden olmuş ve hayatımızda önemli bir yer edinmiştir. Her geçen gün gelişen bilgi ve iletişim teknolojileri, mahalle bakkalından binlerce çalışanı bulunan uluslararası büyüklükteki firmalara kadar her büyüklükte işletmenin üretim, tedarik, muhasebe, finans, insan kaynakları ve pazarlama bölümlerindeki iş süreçlerini derinden etkilemiş, yeni iş modellerinin ortaya çıkması için bir ortam oluşturmuştur. Dünya 
genelinde yaygınlaşması ile birlikte, internet iş hayatında ticari işlemlerin gerçekleştirilmesi için de kullanılmaya başlamış ve e-ticaret kavramı hayatımıza girmiştir.1990'lardan itibaren, elektronik ticaretin (e-ticaret) ortaya çıkması ile iş yapma yöntemlerinde büyük bir değişime tanıkık etmekteyiz; akademisyenler, işletmeler ve hatta bireyler internette ortaya çıkan bu yeni iş yapma biçimine odaklanmıştır (Ngai \& Gunasekaran, 2007).

E-ticaret, örgütler ve kişiler arasındaki ticari işlemlerin dijital olarak yapılması (genelde internet ve WWW üzerinde) ile ilgilidir (Laudon \& Laudon, 2011, 373). E-ticaret, dünya genelinde bireylerin ve işletmelerin hayatlarına çok hızı bir şekilde girmiş ve giderek artan bir oranda kabul görmekte olup, interneti kullanarak yeni bir iş kurmak için uğraşan girişimcilerin de sayısı her geçen gün artmaktadır (Özmen, 2013, 1). İnternet ve ağ teknolojilerinin hızla yaygınlaşması ve popüler hale gelmesi nedeniyle, günümüzde e-ticaret iş operasyonlarında önemli bir etkinlik haline gelmiştir ve önemli ölçüde iş faaliyeti çevrimiçi yapılmaktadır (Wang \& Chen, 2010). Eticaretin hızlı bir şekilde büyümesinin önemli bir nedeni olan WWW ve internetin özgün yapısı ve özellikleri şu şekilde sıralanabilir: aynı anda birçok yerde olma, küresel erişim, evrensel standartlar, enformasyon zenginliği, etkileşim, enformasyon yoğunluğu, kişiselleştirme/özelleştirme ve sosyal teknoloji (Laudon \& Laudon, 2011, 374-378). Yeni ekonomide teknolojide, özellikle bilgi ve iletişim teknolojilerinde, meydana gelen gelişmeler sonucu ortaya çıkan tüm cihazlar, yazılımlar ve mobil uygulamalar, yeni e-iş modellerinin ortaya çıkmasına, eskilerinin ise farklılaşmasına neden olmaktadır (Özmen, 2013, 131). Elektronik ticari işlemler ve e-ticaret farklı şekillerle sınıflandırılabilmekle beraber, ticari işlemleri gerçekleştiren taraflara göre yapılan sınıflandırma sık olarak kullanılmaktadır (Özmen, 2013, 150, Laudon \& Laudon, 2011, 381). Bu sınıflandırmaya göre yaygın şekilde kullanılan e-ticaret çeşitleri, işletmeden tüketiciye e-ticaret (B2C), işletmeden işletmeye e-ticaret (B2B) ve tüketiciden tüketiciye e-ticarettir (C2C) (Laudon \& Laudon, 2011, 381).

Internet World Stats Kasım 2015 verilerine göre dünya nüfusunun yaklaşık \%46,4'ü (3,37 milyar kişi) internet kullanıcısı olup, 2000 yılına göre internet kullanıc sayısında \%832,5 artış gerçekleşmiştir. Türkiye'de ise nüfusun yaklaşık \%59,6'sının (46,3 milyon kişi) internet kullanıcısı olduğu tahmin edilmektedir (Internet World Stats). Türkiye İstatistik Kurumu (TÜiK) tarafından gerçekleştirilen Hanehalkı Bilişim Teknolojileri Kullanım Araştırması sonuçlarına göre ise 2015 yılı Nisan ayında bilgisayar ve internet kullanım oranları 16-74 yaş grubundaki bireylerde sırasıyla \%54,8 ve \%55,9 olarak saptanmıştır. Internet ve e-ticaretin işletmelere ve bireylere sağlayabileceği avantajlara rağmen günümüzde çeşitli nedenlerle bazı işletmeler ve tüketiciler internet üzerinden alışveriş yapmaya çekinmektedirler. TÜiK 2015 yılı Hanehalkı Bilişim Teknolojileri Kullanım Araştırması sonuçlarına göre internet kullanan 16-74 yaş grubu bireylerin \%72,3'ünün son on iki ay içinde (Nisan 2014 - Mart 2015) kişisel kullanım amacıyla internet üzerinden mal ve hizmet siparişi vermediği ya da satın almadığı saptanmıştır. Bunun en önemli nedenlerinin ise "ürünü yerinde görerek alma, satış yapılan dükkana bağııık ve alışkanlıklar" ve "ödemede gizlilik ya da güvenlik kaygıları" olduğu tespit edilmiştir.

\section{TÜRKIYE'DE E-TICARET}

Bu çalışmada ülkemizdeki e-ticaretin yıllar içerisindeki gelişimini ve mevcut durumunu ortaya çıkarabilmek ve analiz edebilmek için Bankalararası Kart Merkezi (BKM) tarafından yayınlanan İnternetten Yapılan Kartlı Ödeme İşlemleri, Türkiye İstatistik Kurumu (TÜiK) tarafından gerçekleştirilen Girişimlerde Bilişim Teknolojileri Kullanım Araştırması ve Hanehalkı Bilişim Teknolojileri Kullanım Araştırması ile Avrupa İstatistik Ofisi (Eurostat) e-ticaret istatistikleri kullanılmıştır.

BKM, 13 kamu ve özel Türk bankasının ortaklığıyla 1990 yılında kurulmuş olup, faaliyetleri şu şekilde özetlenmiştir; "ödeme sistemleri içerisinde; nakit kullanımı gerekmeksizin her türlü ödemeyi veya para transferini sağlayan veya destekleyen sistem, platform ve altyapıları oluşturmak, işletmek ve geliştirmektir" (BKM, 2016). BKM aynı zamanda internetten yapılan kartlı ödeme işlemlerini de takip etmekte ve kartlı ödemelerle ilgili dönemsel istatistikler hazırlamaktadır. Internetten yapılan kartlı ödeme işlemleri istatistikleri ülkemizde yıllar içerinde e-ticaretin gelişimi hakkında önemli bir bilgi kaynağı olarak kabul edilebilir. BKM verilerine göre internetten yapılan kartlı ödeme işlemlerinin hem miktarı, hem de tutarı 2011 yılı ile 2015 yılı arasında artış göstermiş olup, internet üzerinde yerli kartların yurt içi ve yurtdışı kullanımı işlem adedi 2011 yılında 111.059.202 iken \%135 artarak 2015 yılında 260.927.719'a yükselirken, internet üzerinde yerli kartların yurt içi ve yurtdışı kullanımı işlem tutarı 2011 yılında 17.984,91 milyon TL iken \%207 artarak 2015 yılında 55.284,00 milyon TL'ye yükselmiştir (Tablo 1, Tablo 2). 
Tablo 1: internetten Yapılan Kartlı Ödeme iş̧lemleri, Yıllara Göre Işslem Adetleri

\begin{tabular}{|c|c|c|c|c|c|c|}
\hline \multirow{2}{*}{ Yıl } & \multicolumn{7}{|c|}{ İşlem Adedi } \\
\cline { 2 - 7 } & Yerli Kartların Yurt İçi ve Yurtdışı Kullanımı & \multicolumn{2}{c|}{ Yerli ve Yabancı Kartların Yurt İçi Kullanımı } \\
\cline { 2 - 7 } & Yurt İçi & Yurtdışı & Toplam & Yerli Kart & Yabancı Kart & Toplam \\
\hline 2015 & 219.713 .668 & 41.214 .051 & 260.927 .719 & 219.713 .668 & 7.447 .751 & 227.161 .419 \\
\hline 2014 & 181.919 .954 & 36.225 .742 & 218.145 .696 & 181.919 .954 & 8.604 .334 & 190.524 .288 \\
\hline 2013 & 164.395 .488 & 28.929 .367 & 193.324 .855 & 163.809 .183 & 4.252 .173 & 168.061 .356 \\
\hline 2012 & 128.193 .912 & 18.037 .399 & 146.231 .311 & 128.193 .912 & 4.810 .454 & 133.004 .366 \\
\hline 2011 & 98.217 .793 & 12.841 .409 & 111.059 .202 & 98.217 .793 & 4.059 .422 & 102.277 .215 \\
\hline
\end{tabular}

Kaynak: BKM, İnternetten Yapılan Kartlı Ödeme İşlemleri,

Tablo 2: İnternetten Yapılan Kartlı Ödeme İşlemleri, Yıllara Göre İşlem Tutarları

\begin{tabular}{|c|c|c|c|c|c|c|}
\hline \multirow{2}{*}{ Yıl } & \multicolumn{6}{|c|}{ İşlem Tutarı (Milyon TL) } \\
\cline { 2 - 7 } & Yerli Kartların Yurt İçi ve Yurtdışı Kullanımı & \multicolumn{2}{|c|}{ Yerli ve Yabancı Kartların Yurt Icci Kullanımı } \\
\cline { 2 - 7 } & Yurt İçi & Yurtdışı & Toplam & Yerli Kart & Yabancı Kart & Toplam \\
\hline 2015 & $50.682,91$ & $4.601,09$ & $55.284,00$ & $50.682,91$ & $4.706,09$ & $55.389,00$ \\
\hline 2014 & $37.255,39$ & $3.593,29$ & $40.848,68$ & $37.255,39$ & $4.628,05$ & $41.883,44$ \\
\hline 2013 & $31.947,50$ & $2.561,41$ & $34.508,91$ & $31.824,57$ & $2.781,46$ & $34.606,04$ \\
\hline 2012 & $22.882,50$ & $1.904,59$ & $24.787,09$ & $22.882,50$ & $2.295,81$ & $25.178,31$ \\
\hline 2011 & $16.553,79$ & $1.431,12$ & $17.984,91$ & $16.553,79$ & $2.187,09$ & $18.740,88$ \\
\hline
\end{tabular}

Kaynak: BKM, İnternetten Yapılan Kartlı Ödeme İşlemleri,

TÜiK tarafından gerçekleştirilen Girişimlerde Bilişim Teknolojileri Kullanım Araştırması verilerine göre araştırma kapsamındaki işletmelerin \%90'dan fazlası 2015 yılında internet erişimine sahipken, web sayfası/sitesine sahip olan işletme oranı sadece 250 ve üzeri çalışanı olan işletmelerde \%90'dan yüksektir. Web sayfası/sitesine sahip olan işletme oranları 10-49 arası çalışanı olan işletmelerde \%61,6, 50-249 arası çalışanı olan işletmelerde \%79,7, 250 ve üzeri çalışanı olan işletmelerde de \%90,9 olarak tespit edilmiştir (Tablo 3, Tablo 4).

Tablo 3: Çalışan Büyüklük Grubuna Göre Girişimlerde İnternet Erişimine Sahiplik Oranı

\begin{tabular}{|c|c|c|c|}
\hline & $\mathbf{1 0 - 4 9}$ & $\mathbf{5 0 - 2 4 9}$ & 250 ve üzeri \\
\hline Yıl & $(\%)$ & $(\%)$ & $(\%)$ \\
\hline 2015 & 91,1 & 98,0 & 99,5 \\
\hline 2014 & 88,5 & 96,1 & 98,7 \\
\hline 2013 & 89,3 & 97,0 & 98,8 \\
\hline 2012 & 91,2 & 98,1 & 99,6 \\
\hline 2011 & 91,4 & 96,7 & 99,0 \\
\hline
\end{tabular}

Kaynak: TÜiK Girişimlerde Bilişim Teknolojileri Kullanım Araştırması

Tablo 4: Çalışan Büyüklük Grubuna Göre Girişimlerde Web Sayfası/Sitesi Sahiplik Oranı

\begin{tabular}{|c|c|c|c|}
\hline & $\mathbf{1 0 - 4 9}$ & $\mathbf{5 0 - 2 4 9}$ & 250 ve üzeri \\
\hline Yıl & $(\%)$ & $(\%)$ & $(\%)$ \\
\hline 2015 & 61,6 & 79,7 & 90,9 \\
\hline 2014 & 52,3 & 73,5 & 87,3 \\
\hline 2013 & 50,0 & 68,5 & 83,2 \\
\hline 2012 & 54,2 & 74,6 & 88,3 \\
\hline 2011 & 51,2 & 71,7 & 86,0 \\
\hline
\end{tabular}

Kaynak: TÜiK Girişimlerde Bilişim Teknolojileri Kullanım Araştırması 
TÜiK Girişimlerde Bilişim Teknolojileri Kullanım Araştırması sonuçlarına göre Web sitesi üzerinden veya elektronik veri alışverişi (EDI) ile ürün/hizmet siparişi alan girişimlerin sayısı oldukça sınırlı olup, 2014 yılında araştırma kapsamındaki 10-49 arası çalışanı olan işletmelerin \%11,5'u, 50-249 arası çalışanı olan işletmelerin \%15,1'i, 250 ve üzeri çalışanı olan işletmelerin de \%20,4'ü Web sitesi üzerinden veya elektronik veri alışverişi (EDI) ile ürün/hizmet siparişi almıştır (Tablo 5). Sosyal medya uygulamalarını kullanan girişimlerin oranları ise 2015 yılında sırasıyla 10-49 arası çalışanı olan işletmelerde \%36,8, 50-249 arası çalışanı olan işletmelerde \%45,9, 250 ve üzeri çalışanı olan işletmelerde \%54,9 olarak saptanmıştır (Tablo 6).

Tablo 5: Web Sitesi Üzerinden veya Elektronik Veri Alışverişi (EDI) ile Ürün/Hizmet Siparişi Alan Girişimler

\begin{tabular}{|c|c|c|c|}
\hline & $\mathbf{1 0 - 4 9}$ & $\mathbf{5 0 - 2 4 9}$ & $\mathbf{2 5 0}$ ve üzeri \\
\hline Y.l & (\%) & $(\%)$ & (\%) \\
\hline 2014 & 11,5 & 15,1 & 20,4 \\
\hline 2013 & 8,1 & 9,3 & 17,7 \\
\hline 2012 & 9,2 & 12,6 & 21,8 \\
\hline 2011 & 10,5 & 12,7 & 18,8 \\
\hline
\end{tabular}

Kaynak: TÜiK Girişimlerde Bilişim Teknolojileri Kullanım Araştırması

Tablo 6: Sosyal Medya Uygulamalarını Kullanan Girişimler

\begin{tabular}{|c|c|c|c|}
\hline & $\mathbf{1 0 - 4 9}$ & $\mathbf{5 0 - 2 4 9}$ & 250 ve üzeri \\
\hline Yıl & (\%) & (\%) & (\%) \\
\hline 2015 & 36,8 & 45,9 & 54,9 \\
\hline 2014 & 25,7 & 35,0 & 44,8 \\
\hline 2013 & 25,5 & 30,1 & 42,5 \\
\hline
\end{tabular}

Kaynak: TÜiK Girişimlerde Bilişim Teknolojileri Kullanım Araştırması

TÜik tarafından gerçekleştirilen Hanehalkı Bilişim Teknolojileri Kullanım Araştırması sonuçlarına göre 2015 yılında araştırma kapsamındaki 16-74 yaş grubu bireylerin \%54,8'inin bilgisayar ve \%55,9'unun internet kullandığı saptanmıştır. Ülkemizde erkek ve kadınlar arasında bu teknolojilerin kullanımı açısından önemli farklılıklar bulunmaktadır. TÜik 2015 yılı Hanehalkı Bilişim Teknolojileri Kullanım Araştırmasında bilgisayar ve internet kullanım oranları erkeklerde $\% 64$ ve $\% 65,8$, kadınlarda ise $\% 45,6$ ve $\% 46,1$ olarak saptanmıştır. Erkekler ve kadınlar arasında bu teknolojilerin kullanımı açısından gözlemlenen fark 2013 ve 2014 yıllarında da dikkat çekmektedir (Tablo 7).

Tablo 7: 16-74 yaş Grubu Bireylerin Bilgisayar ve İnternet Kullanım Oranı

\begin{tabular}{|c|c|c|c|c|c|c|}
\hline & \multicolumn{3}{|c|}{ Bilgisayar } & \multicolumn{3}{c|}{ internet } \\
\hline & Toplam & Erkek & Kadın & Toplam & Erkek & Kadın \\
\hline Yıl & $(\%)$ & $(\%)$ & $(\%)$ & $(\%)$ & $(\%)$ & $(\%)$ \\
\hline 2015 & 54,8 & 64,0 & 45,6 & 55,9 & 65,8 & 46,1 \\
\hline 2014 & 53,5 & 62,7 & 44,3 & 53,8 & 63,5 & 44,1 \\
\hline 2013 & 49,9 & 60,2 & 39,8 & 48,9 & 59,3 & 38,7 \\
\hline
\end{tabular}

Kaynak: TÜiK Hanehalkı Bilişim Teknolojileri Kullanım Araştırması

TÜiK 2015 yılı Hanehalkı Bilişim Teknolojileri Kullanım Araştırması sonuçlarına göre internet kullanan 16-74 yaş grubu bireylerin kişisel kullanım amacıyla internet üzerinden mal veya hizmet siparişi verme ya da satın alma oranı 2014 'de \%30,8 iken 2015 'de bu oran \%33,1'e çıkmıştır (Tablo 8). Internet kullanan erkeklerin kadınlara göre küçük bir farkla internet üzerinden daha fazla mal veya hizmet siparişi verdiği ya da satın aldığı gözlenmektedir. 
Tablo 8: 16-74 Yaş Grubu Bireylerin Kişisel Kullanım Amacıyla İnternet Üzerinden Mal veya Hizmet Siparişi Verme ya da Satın Alma Oranı

\begin{tabular}{|c|c|c|c|}
\hline & \multicolumn{3}{|c|}{ Internet kullanan bireyler içinde (\%) } \\
\hline Yıl & Toplam & Erkek & Kadın \\
\hline 2015 & 33,1 & 33,3 & 32,9 \\
\hline 2014 & 30,8 & 32,4 & 28,4 \\
\hline 2013 & 24,1 & - & - \\
\hline
\end{tabular}

Kaynak: TÜiK Hanehalkı Bilişim Teknolojileri Kullanım Araştırması

TÜiK 2015 yılı Hanehalkı Bilişim Teknolojileri Kullanım Araştırması sonuçlarına göre internet üzerinden kişisel kullanım amacıyla alışveriş yapan 16-74 yaş grubu bireylerin 2014 yılı Nisan ile 2015 yılı Mart aylarını kapsayan on iki aylık dönemde en fazla almış oldukları ürün ve hizmete göre sıralandığında; \%57,4'ünün giyim ve spor malzemesi, \%27'sinin seyahat ile ilgili diğer faaliyetler (seyahat bileti, araç kiralama vb.), \%25,5'inin ev eşyası (Mobilya, oyuncak, beyaz eşya vb), \%22,4'ünün elektronik araçlar (Cep telefonu, kamera, radyo, TV, DVD oynatıcı vb.) ve \%18,4'ünün kitap, dergi, gazete (e-kitap dahil) aldığı saptanmıştır (Tablo 9).

Tablo 9: Son 12 Ay İçinde (Nisan 2014 - Mart 2015) Kişisel Kullanım Amacıyla 16-74 Yaş Grubu Bireylerin İnternet Üzerinden Sipariş Verdiği ya da Satın Aldığı Mal ve Hizmet Türleri, 2015

\begin{tabular}{|l|c|c|c|}
\hline & \multicolumn{3}{|c|}{$\begin{array}{c}\text { Son 12 ay içinde internet } \\
\text { üzerinden mal veya hizmet } \\
\text { siparişi verenler ya da satın } \\
\text { alanlar içinde }\end{array}$} \\
\hline Mal ve hizmet türleri & \multicolumn{2}{|c|}{ Koplam } & Erkek \\
\hline Gıda maddeleri ile günlük gereksinimler & 17,4 & 13,8 & 22,3 \\
\hline Ev eşyası (Mobilya, oyuncak, beyaz eşya vb) & 25,5 & 25,3 & 25,8 \\
\hline ilaç & 3,1 & 3,3 & 2,8 \\
\hline Giyim, spor malzemeleri & 57,4 & 48,1 & 70,5 \\
\hline Bilgisayar ve diğer ek donanım & 12,1 & 16,2 & 6,4 \\
\hline Elektronik araçlar (Cep telefonu, kamera, radyo, TV, DVD oynatıcı vb.) & 22,4 & 30,5 & 11,0 \\
\hline $\begin{array}{l}\text { Telekominikasyon hizmetleri (TV, genişbant abonelik hizmetleri (ADSL } \\
\text { vb.), sabit veya cep telefonu abonelikleri, ön ödemeli telefon kartları } \\
\text { için para yükleme/yatırma }\end{array}$ & 5,8 & 7,6 & 3,3 \\
\hline Hisse senedi / Finansal hizmet / Sigorta alımı & 2,6 & 3,4 & 1,4 \\
\hline Konaklama (Otel vb. rezervasyon) & 14,3 & 14,6 & 13,8 \\
\hline Seyahat ile ilgili diğer faaliyetler (seyahat bileti, araç kiralama vb.) & 27,0 & 29,7 & 23,1 \\
\hline $\begin{array}{l}\text { Sportif ve kültürel faaliyetler için bilet satın alımı (sinema, tiyatro, } \\
\text { konser, maç vb.) }\end{array}$ & 14,8 & 15,4 & 13,9 \\
\hline Film, müzik & 6,9 & 7,4 & 6,2 \\
\hline Kitap, dergi, gazete (e-kitap dahil) & 18,4 & 17,7 & 19,4 \\
\hline e-öğrenme araçları (çevrimiçi eğitim siteleri, CD vb.) & 3,9 & 4,3 & 3,3 \\
\hline Oyun yazılımı, diğer bilgisayar yazılımı ve yazılım güncellemeleri & 5,9 & 7,6 & 3,5 \\
\hline Diğer & 0,4 & 0,5 & 0,4 \\
\hline
\end{tabular}

Kaynak: TÜiK Hanehalkı Bilişim Teknolojileri Kullanım Araştırması

TÜik 2015 yılı Hanehalkı Bilişim Teknolojileri Kullanım Araştırması sonuçlarına göre 2014 yılı Nisan ile 2015 yılı Mart aylarını kapsayan on iki aylık dönemde internet üzerinden kişisel kullanım amacıyla satın alış ya da sipariş veren 16-74 yaş grubu bireylerin \%23,2'si sorun yaşadı. Sorun yaşayanların en çok karşılaştıkları sorun türü ise sırasıyla; "teslimatın belirtilenden daha yavaş olması" (\%47) ve "yanlış veya hasarlı ürün veya hizmetin teslim edilmesi" $(\% 45,4)$ olarak saptanmıştır (Tablo 10). 
Tablo 10: Son 12 Ay İçinde (Nisan 2014 - Mart 2015) Kişisel Kullanım Amacıyla İnternet Üzerinden Satın Alış ya da Sipariş Vermede Sorun Yaşayan 16-74 Yaş Grubu Bireylerin Oranı ve Sorun Türleri, 2015, (\%)

\begin{tabular}{|l|c|c|c|}
\hline & Toplam & Erkek & Kadın \\
\hline Sorun yaşayanlar & 23,2 & 23,1 & 23,3 \\
\hline Sorun yaşayan bireylerin karşılaştıkları sorun türleri & & \\
\hline Sipariş veya ödeme aşamasında web sitesinde karşılaşılan teknik arıza & 20,3 & 20,5 & 20,1 \\
\hline Garanti koşulları ve diğer kanuni haklara ilişkin bilgi bulmanın zor olması & 12,6 & 13,2 & 11,9 \\
\hline Teslimatın belirtilenden daha yavaş olması & 47,0 & 45,0 & 49,6 \\
\hline $\begin{array}{l}\text { Ürün veya hizmet fiyatının belirtilenden daha yüksek olması (örn: } \\
\text { beklenmeyen işlem masrafları veya yüksek teslimat ücreti) }\end{array}$ & 11,4 & 10,5 & 12,6 \\
\hline Yanlış veya hasarlı ürün veya hizmetin teslim edilmesi & 45,4 & 45,1 & 45,8 \\
\hline $\begin{array}{l}\text { Dolandırıılık (örn: Ürün veya hizmetin teslim edilmemesi, kredi kartı } \\
\text { bilgilerinin kötüye kullanması vb.) }\end{array}$ & 10,8 & 12,1 & 8,9 \\
\hline $\begin{array}{l}\text { Şikayet ve tazmindeki zorluklar veya şikayet sonrası tatmin edici cevaplar } \\
\text { alınamaması }\end{array}$ & 18,1 & 19,5 & 16,2 \\
\hline Yurt dışı menşeli web sitelerinden ülkeye mal ve hizmet satılmaması & 9,7 & 10,4 & 8,6 \\
\hline Diğer & 1,6 & 1,9 & 1,2 \\
\hline
\end{tabular}

Kaynak: TÜiK Hanehalkı Bilişim Teknolojileri Kullanım Araştırması

TÜiK 2015 yılı Hanehalkı Bilişim Teknolojileri Kullanım Araştırması sonuçlarına göre internet kullanan 16-74 yaş grubu bireylerin içerisinde \%72,3'ünün son on iki ay içinde (Nisan 2014 - Mart 2015) kişisel kullanım amacıyla internet üzerinden mal ve hizmet siparişi vermediği ya da satın almadığı saptanmıştır (Tablo 11). Bunun en önemli nedenlerinin ise "ürünü yerinde görerek alma, satış yapılan dükkana bağlılık ve alışkanlıklar" $(\% 81,2)$ ve "ödemede gizlilik ya da güvenlik kaygıları" (\%44,9) olduğu tespit edilmiştir.

Tablo 11: İnternet Kullanan 16-74 Yaş Grubu Bireylerin Son On İki Ay İçinde (Nisan 2014 - Mart 2015) Kişisel Kullanım Amacıyla İnternet Üzerinden Mal ve Hizmet Siparişi Vermeme ya da Satın Almama Nedenleri, 2015,

(\%)

\begin{tabular}{|c|c|c|c|}
\hline & Toplam & Erkek & Kadın \\
\hline $\begin{array}{l}\text { Internet kullanan bireylerden son on iki ay içinde internet üzerinden mal ve } \\
\text { hizmet siparişi vermeyenler ya da satın almayanlar }\end{array}$ & 72,3 & 72,5 & 72,0 \\
\hline \multicolumn{4}{|l|}{ Nedenler } \\
\hline Ürünü yerinde görerek alma, satış yapılan dükkana bağlılık ve alışkanlıklar & 81,2 & 81,7 & 80,4 \\
\hline Bilgi ve beceri eksikliği & 21,0 & 20,4 & 21,8 \\
\hline İnternet üzerinden sipariş edilen malların teslim problemi & 20,3 & 20,8 & 19,6 \\
\hline Ödemede gizlilik ya da güvenlik kaygıları & 44,9 & 45,7 & 43,6 \\
\hline $\begin{array}{l}\text { Ürünü teslim alma, iade etme ya da şikayet ile ilgili sorun giderme konusunda } \\
\text { güvensizlik }\end{array}$ & 27,0 & 27,5 & 26,2 \\
\hline İnternet üzerinden ödeme olanağı veren kredi kartı olmaması & 16,2 & 14,4 & 18,8 \\
\hline Diğer & 4,0 & 3,7 & 4,6 \\
\hline
\end{tabular}

Kaynak: TÜiK Hanehalkı Bilişim Teknolojileri Kullanım Araştırması

Eurostat istatistiklerine göre Avrupa Birliği (AB) üyesi 28 ülkede yaşayan 16-74 yaş arası bireylerin \%81'inin son bir yıl içerisinde internet kullandığı, \%16'sının ise hiç internet kullanmadığı ve kişisel kullanım amacıyla internet üzerinden mal veya hizmet siparişi veren ya da satın alanların oranının \%53 (16-74 yaş arası internet kullanıcılarının \%65'i) olduğu saptanmıştır. Eurostat istatistiklerine göre Türkiye'de 16-74 yaş arası bireyler arasında son 12 ayda internet kullananların oranı \%54, hiç internet kullanmayanların oranı \%44 ve kişisel kullanım amacıyla internet üzerinden mal veya hizmet siparişi veren ya da satın alanların oranı \%15 olup, bu 
oranlar AB ile kıyaslandığında oldukça düşüktür. Romanya hariç bütün AB ülkeleri için kişisel kullanım amacıyla internet üzerinden mal veya hizmet siparişi veren ya da satın alanların oranı, ülkemizden daha yüksektir.

Tablo 12: Avrupa Birliğinde İnternet Kullanımı ve E-Ticaret Verileri (16-74 Yaş Arası Bireyler)

\begin{tabular}{|c|c|c|c|c|c|c|}
\hline & $\begin{array}{c}\text { Son } 3 \text { ay } \\
\text { içinde } \\
\text { internet } \\
\text { kullanan } \\
\text { bireyler (\%) }\end{array}$ & $\begin{array}{l}\text { Son } 12 \text { ay } \\
\text { içinde } \\
\text { internet } \\
\text { kullanan } \\
\text { bireyler (\%) }\end{array}$ & $\begin{array}{l}\text { Hiç internet } \\
\text { kullanmamış } \\
\text { bireyler (\%) }\end{array}$ & $\begin{array}{l}\text { Her gün veya } \\
\text { hemen her } \\
\text { gün internet } \\
\text { kullananlar } \\
\text { (\%) }\end{array}$ & $\begin{array}{l}\text { En azından } \\
\text { haftada bir } \\
\text { internet } \\
\text { kullananlar } \\
\text { (Günlük } \\
\text { kullanım } \\
\text { dahil) (\%) }\end{array}$ & $\begin{array}{c}\text { Son on iki ay } \\
\text { içinde çevrim } \\
\text { içi satın alma } \\
\text { yapan } \\
\text { bireylerin } \\
\text { yüzdesi }\end{array}$ \\
\hline AB-28 & 79 & 81 & 16 & 67 & 76 & 53 \\
\hline Belçika & 85 & 86 & 13 & 73 & 83 & 55 \\
\hline Bulgaristan & 57 & 60 & 35 & 46 & 55 & 18 \\
\hline Çek Cumhur. & 81 & 83 & 13 & 63 & 77 & 45 \\
\hline Danimarka & 96 & 97 & 3 & 87 & 93 & 79 \\
\hline Almanya & 88 & 89 & 10 & 75 & 84 & 73 \\
\hline Estonya & 88 & 89 & 9 & 77 & 86 & 59 \\
\hline İrlanda & 80 & 82 & 16 & 67 & 78 & 51 \\
\hline Yunanistan & 67 & 68 & 30 & 55 & 63 & 32 \\
\hline İspanya & 79 & 80 & 19 & 64 & 75 & 42 \\
\hline Fransa & 85 & 87 & 11 & 68 & 81 & 65 \\
\hline Hırvatistan & 70 & 71 & 26 & 60 & 66 & 31 \\
\hline İtalya & 66 & 68 & 28 & 62 & 63 & 26 \\
\hline Kıbris & 72 & 72 & 26 & 63 & 70 & 23 \\
\hline Letonya & 79 & 80 & 18 & 66 & 75 & 38 \\
\hline Litvanya & 71 & 72 & 25 & 56 & 69 & 32 \\
\hline Lüksemburg & 97 & 98 & 2 & 92 & 97 & 78 \\
\hline Macaristan & 73 & 76 & 21 & 63 & 72 & 36 \\
\hline Malta & 76 & 77 & 22 & 69 & 74 & 51 \\
\hline Hollanda & 93 & 94 & 4 & 85 & 91 & 71 \\
\hline Avusturya & 84 & 85 & 13 & 68 & 81 & 58 \\
\hline Polonya & 68 & 70 & 27 & 52 & 65 & 37 \\
\hline Portekiz & 69 & 70 & 28 & 55 & 65 & 31 \\
\hline Romanya & 56 & 62 & 32 & 37 & 52 & 11 \\
\hline Slovenya & 73 & 75 & 22 & 61 & 71 & 39 \\
\hline Slovakya & 78 & 81 & 16 & 60 & 74 & 50 \\
\hline Finlandiya & 93 & 93 & 5 & 85 & 91 & 71 \\
\hline İsveç & 91 & 92 & 5 & 82 & 89 & 71 \\
\hline Ingiltere & 92 & 93 & 6 & 83 & 90 & 81 \\
\hline Norveç & 97 & 97 & 1 & 89 & 96 & 76 \\
\hline Makedonya & 70 & 73 & 26 & 60 & 69 & 11 \\
\hline Türkiye & 52 & 54 & 44 & 40 & 48 & 15 \\
\hline
\end{tabular}

Kaynak: Eurostat, E-commerce statistics for individuals

\section{SONUÇ VE DEĞERLENDIRME}

İnternetin 1990'lardan itibaren dünya genelinde hızla yaygınlaşmaya başlaması ve günümüzde mobil akıllı cihazlarla birlikte hemen her yerden internete erişimin olanaklı hale gelmesi, günlük hayatımızda da beklenen veya beklenmeyen önemli değişiklilere neden olmuş ve bu teknolojiler, her geçen gün hayatımızda daha fazla 
yer edinmiştir. Günümüz dünyasında internet ve $W W W$ 'in en çok etkilediği bir alan da iş hayatı ve alışveriş alışkanlıklarımızdır. Işletmelerin, özellikle KOBi'lerin, interneti etkin bir şekilde kullanmaları günümüz şartlarında küreselleşen rekabete ayak uydurmaları ve rekabet avantajı elde edebilmeleri açısından büyük önem taşımaktadır.

Ülkemizde yıllar itibariyle internet kullanıcı sayısı, internet üzerinden alışveriş yapanların sayısı ve internet üzerinde faaliyet gösteren işletme sayısı artmış olmasına rağmen, gerek internet kullanıcı oranları gerekse eticaret yapanların oranları Avrupa Birliği ülkeleri ile karşılaştırıldı̆ında, ülkemizin bu konudaki durumunun çok da iyi olmadığı anlaşıımaktadır. İnternet kullanımı ve e-ticaret farkındalığının arttıııması, e-girişimciliğin teşvik edilmesi, işletmelerin interneti iş süreçlerinde kullanmaları ve WWW üzerinde faaliyet göstermesinin teşvik edilerek, bu konu ile ilgili gerek girişimciler gerekse tüketicilerin karşılaşmış oldukları engel ve problemlere yönelik uygun önlemlerin alınması gerekmektedir.

\section{KAYNAKLAR}

BKM, İnternetten Yapılan Kartlı Ödeme İşlemleri, http://bkm.com.tr/internetten-yapilan-kartli-odeme-islemleri/ Erişim Tarihi: 15.03 .2016

BKM, Tarihçe, http://bkm.com.tr/bkm-hakkinda/bkmyi-taniyin/tarihce/ Erişim Tarihi: 20.03.2016

Eurostat, E-commerce statistics for individuals, http://ec.europa.eu/eurostat/statistics-explained/index.php/Ecommerce statistics for individuals Erişim Tarihi: 21.03.2016

Eurostat, E-commerce statistics, http://ec.europa.eu/eurostat/statistics-explained/index.php/E-commerce statistics Erişim Tarihi: 21.03.2016

Internet World Stats, World Internet Users and 2015 Population Stats, http://www.internetworldstats.com/stats.htm Erişim Tarihi: 21.03.2016

Internet World Stats, Internet in Europe Stats, http://www.internetworldstats.com/stats4.htm Erişim Tarihi: 21.03.2016

Laudon, K. C. \& Laudon, J. P. (2011). Yönetim Bilişim Sistemleri Dijital Işletmeyi Yönetme. U. Yozgat (Çev). 12. Basım. Nobel Yayınları, Ankara.

Ngai, E. W. T. \& Gunasekaran, A. (2007). A review for mobile commerce research and applications, Decision Support Systems, 43, 3-15.

Özmen, Ş. (2013). Ağ Ekonomisinde Yeni Ticaret Yolu: E-Ticaret, Genişletilmiş 5. Baskı, İstanbul Bilgi Üniversitesi Yayınları, i̇stanbul.

TÜik (2015). Hanehalkı Bilişim Teknolojileri Kullanım Araştırması, http://www.tuik.gov.tr/PreTablo.do?alt id=1028, Erişim Tarihi: 18.02.2016.

TÜiK (2015). Girişimlerde Bilişim Teknolojileri Kullanım Araştırması, http://www.tuik.gov.tr/PreTablo.do?alt id=1048 Erişim Tarihi: 18.02.2016

Wang, C. C. \& Chen, C. C. (2010). Electronic Commerce Research in Latest Decade: A Literature Review, International Journal of Electronic Commerce Studies, 1(1), 1-14. 